\title{
Value Creation Through International Acquisitions In A World Of One-Way Globalization: Toward A New Paradigm
}

Kathleen Park, Massachusetts Institute of Technology, USA Robert G. Vambery, Pace University, USA

\begin{abstract}
Cross-border mergers and acquisitions have typically resulted in relatively poor returns for acquiring firm shareholders. Yet subsets from the universe of $M \& A$ deals have demonstrated positive returns, leaving open the question of determining the characteristics of cross-border deals that would be conducive to wealth formation. We use a study of large-capitalization firms as a springboard to investigating the performance of differentiated large-scale international acquisitions. We note that large acquisitions take place in a world frequently characterized by one-way rather than reciprocal globalization. This ongoing study seeks to identify determinants of value creation subject to imbalances in how the benefits from transnational business processes are distributed among the countries which accommodate the transactions.
\end{abstract}

Keywords: Mergers \& Acquisitions, Globalization, Trade Imbalances

\section{INTRODUCTION: THE CROSS-BORDER DEALMAKING PHENOMENON}

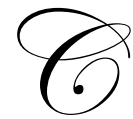

ross-border mergers and acquisitions (M\&A) have been a notable feature of the global merger wave. The present merger wave began in 2003 following a two-year slowdown in dealmaking, corresponding to a worldwide cooling in stock markets at the turn of the millennium (Harford, 2005). Mergers and acquisitions previously occurred in five distinct waves between 1890 and 2000, with each era of transaction intensification triggered by favorable economic, technological, regulatory, equity, and liquidity conditions (Auster \& Sirower, 2002; Shleifer \& Vishny, 2003). M\&A activity reached unprecedented levels in the 1993-2000 wave when over 58,000 firms combined in the global exchange of over $\$ 12$ trillion in assets (Selden \& Colvin, 2003).

While recent research establishes that cross-border deals have been a consistent source of value destruction (e.g., Datta \& Puia, 1995; Moeller \& Schlingemann, 2005), such deals have not only persisted but over the past two decades have grown in size and number to encompass partnerships between firms from ever more nations (Conn \& Connell, 1990; FactSet Mergerstat, 2004; Harris \& Ravenscraft, 1991). Whereas the US was once by far the most frequent acquirer in international transactions, the dominance now trends toward the European and Asian markets as well. For instance, considering all M\&A deals whether international or domestic, the European deal flow for 2006 YTD exceeds twice the value for the comparable time period in 2005, whereas the US deal flow for 2006 YTD only approximates that for the same time period in 2005 (FactSet Mergerstat, 2006).

Dealmaking has surged in the post-millennial merger era. According to FactSet Mergerstat, the worldwide value of mergers and acquisitions totaled $\$ 1.5$ trillion in 2004 then $\$ 2$ trillion in 2005 . In order of increasing deal valuation, the Latin America, Middle East and Africa, Asia-Pacific, Europe, and US markets contributed to those annual totals. Cross-border deals from all regions (including only deals between publicly-traded firms with a minimum target purchase price of \$1 million) amounted to \$287B in 2004 and \$306B in 2005, representing 19\% and $15 \%$ of the M\&A global markets for the respective years. Thus for those two years in which the reporting of M\&A deals has become increasingly global in perspective, the overall value of international deals rose, while their share of the global market for corporate control somewhat fell. Still, considering the increase in international M\&A 
incidence over the past two decades (Cakici, Hessel, \& Tandon, 1996; Conn et al., 1990; Markides \& Oyon, 1998), cross-border dealmaking clearly emerges as salient in the reorganization of the corporate landscape.

International acquisitions and alliances represent a major form of foreign direct investment (FDI) (Davis \& Nair, 2003; Harris et al., 1991; Park \& Dittrich, 2004). Annual worldwide FDI escalated from $\$ 55$ billion circa 1980 to over \$200 billion in 1990 to almost \$1.4 trillion in 2000 (Mody, 2004). Eighty percent of this investment or about $\$ 1.1$ trillion of the year 2000 amount came from cross-border acquisitions (for all sizes and types of firms), confirming international M\&A deals as a formidable component of FDI and a force in the global allocation of boundaryless capital.

In Europe, many cross-border purchases signify a continuing consolidation within the telecommunications and energy sectors that reinforce the industrialized, high-technology status of the economically developed nations (Global Finance, 2006). For instance, early in 2006 German power and gas provider E.On publicized its \$57 billion accepted bid for Spanish counterpart Endesa. This bid marks the largest utility acquisition ever and enables E.On to become a global leader in power and gas, reaching 50 million customers in 30 countries. Moving westward, British utility National Grid has announced the $\$ 11$ billion acquisition of Brooklyn, New York-based KeySpan. Not to be left behind, French energy utility Suez has bid to acquire the 49\% interest in Belgian power utility Electrabel it does not already own. (Meanwhile, in an example of fervent domestic dealmaking, French state-controlled utility Gaz de France has bid to acquire Suez, and an EU condition for deal completion may be the divestiture of Electrabel). Further evidencing the heated cross-border combining, British telecom Vodafone is rumored to be positioning a takeover bid for French media and entertainment firm Vivendi, a previously underperforming colossus that restructured and retained key mobile telecommunications assets desirable to telecom competitors (Le Figaro, 2006).

\section{OVERVIEW OF ONE-WAY GLOBALIZATION}

The academic discussions of globalization went into high gear during the 1980s, inspired by Theodore Levitt's (1983) seminal work concerning the development of global markets and the potential as well as necessity for creating globally distributed products. Levitt observed that the easing of technology transfer processes, improvements in the speed of transportation operations, reductions in the unit costs of physical distribution, and the lowering of tariff and non-tariff barriers to trade facilitated the process of marketing products across national boundaries and over great distances. Levitt further observed similar earnings capabilities among large groups of consumers the world over, important convergences in customer preferences, and similar methods of product use which made it possible to develop highly, though not necessarily completely, standardized products. He referred to them as global products.

The ability to research, develop, produce and distribute global products for global markets enables firms to achieve radical cost savings and reach dramatic economies of scale. The savings and the resulting reductions in unit costs can be complemented by the judicious use of sophisticated advances in information and computing technology (ICT), resulting in enhanced profitability. Somewhat aggressively, Levitt predicted that those business organizations neglecting to take advantage of the opportunities to create new global marketing strategies would loose out in the brutal and highly competitive new world of global marketing.

In the decades since Levitt popularized the term global products, the concept of globalization has had dramatic impacts on international business activities. At the beginning of the $21^{\text {st }}$ century, the world views globalization, alternatively known as internationalization, as a broad process of eradicating unnecessary restrictions to global commerce. Globalization implies the full opening of markets to international trade, in which additionally (1) financial markets for both portfolio and direct investment opportunities have become more accessible, allowing short and long-term capital to be moved across national borders to global financial centers without significant impediments from either national or regional regulatory agencies; (2) many obstacles to information flows have been removed and the speed of data exchanges has increased substantially; (3) technology transfers have greatly expanded and occur more rapidly as fewer regulations impede their flow, and (4) labor markets for more specialized talent and higher numbers of workers have been enlarged through the cross-border migration of prospective workers (Bhagwati, 1999; Vambery \& Gabberty, 1999). 
The new globalized world is assumed to be one not only of greatly increased mobility but also of reciprocal openness. Indeed, we may find that most countries have opened up somewhat, relative to practices in the pre-globalization era, but that some, including some enormously important nations, have engaged in what may be referred to as one-way globalization. This practice does not imply that they failed to open up to a significant degree, but rather that they are benefiting from a radically greater degree of access to important portions of the world market without providing corresponding degrees or amounts of access to their own national markets.

A leading and enduring case of one-way globalization is the business relationship between Japan and the US (Mann, 1999; Reich \& Mankin, 1986; Shoppa, 1997). Japan, once a largely closed (isolationist) nation, has become more accessible to foreign producers and investors; but the access of foreign nations to Japan is radically less than the access of Japan to foreign nations such as the US. As part of our paper, we examine this dramatic paradox in globalization (the globalization paradox of asymmetrical access) faced by international marketers. The paper scrutinizes imbalances in international macro-marketing access, as related to international acquisition and alliance activity. We continue now to focus on the Japan-US case, and in future versions we consider additional pertinent cross-border scenarios, such as the rising relationship of China and the US.

At the beginning of 2002, the members of the G-8 grew increasingly concerned about the decade-long stagnation of the Japanese economy (Bergsten, 2002). Japan's lack of growth curtailed opportunities for its trading partners to supply goods and services to Japan's markets and to engage in mergers and acquisitions involving Japanese firms; the curtailed growth may also have reduced the availability of importable funds for productive capital investments. During his meetings with US President Bush in February 2002, Japanese Prime Minister Koizumi expressed the hope that the accelerated growth of the US that would help Japan to increase its exports and emerge from recession. Nonetheless, it is common knowledge that over the past 30 years Japan has maintained a substantial trade imbalance with the US. The merchandise trade surpluses with the US developed as early as 1961, heightened to $\$ 80$ billion per annum during the 1980 s, and then shrank to approximately $\$ 60$ billion per annum by the mid-1990s. More recently and through 2008, the annual imbalance remains at about $\$ 80-85$ billion. (In comparison and for future exploration, the US is running annual \$250 billion trade deficits with China in what has become the largest trading relationship in the world.)

During the 1950s, Japan began evolving from the shambles of the immediate aftermath of WWII to a level of development representing a thoroughly reconstructed and highly modernized national productive capacity. In the 1960s, Japan gradually strengthened its export-oriented international competitiveness. During the 1970s and 1980s, it became truly an export juggernaut (Vambery \& Gabberty, 1996). In the 1990s, despite the fact that its economic bubble burst and its domestic economy stagnated, Japan retained the ability to maintain trade surpluses (Lincoln, 2001). Now in the $21^{\text {st }}$ century, it is re-emerging as an overwhelming competitor in key export markets, especially those related to the US.

Should the reader dismiss the validity of the above statements, it is useful to note that the cumulative merchandise trade surplus amassed by Japan since 1950 is about $\$ 1.5$ trillion This sum, adjusted for inflation and interest in 2008 dollars, amounts to over $\$ 2.5$ trillion, which is of a similar order of magnitude as the non-trust-fundprograms-related national debt accumulated by the US government over the same time period.

\section{METHODS AND RESULTS}

We use a comparative study of M\&A-enhanced large-capitalization firms to investigate the short and longterm performance of large-scale international acquisitions. Next, we expand the study to an examination of the reciprocity that investment-making and investment-receiving countries afford to one another in international transactions. Through the synthesis of these two approaches, we seek to generate insights into the value creation process and the resultant sharing of benefits among corporations, stockholders, employees and citizens of the involved countries.

\section{AUTHOR INFORMATION}

Kathleen Park (Ph.D. MIT) is a Postdoctoral Research Fellow at the MIT Sloan School of Management and a Fellow of the Corporate Law and Accountability Research Group in the Faculty of Business and Economics at Monash University. kmpark@mit.edu 
Robert G. Vambery (Ph.D. Columbia University) is Professor of Marketing and International Business at the Pace University Lubin School of Business. Dr. Vambery received the Global Business and Technology Association's Global Excellence Award for his keynote presentation entitled "When Transparency Is Not Enough: from Global Financial Crises to Ethical and Environmental Challenges" delivered before 200 professors from some 40 countries at the Association's Tenth Annual International Conference held in Madrid, Spain. rvambery@ pace.edu

\section{REFERENCES}

1. Auster, E. R. \& Sirower, M. L. 2002. The dynamics of merger and acquisition waves. Journal of Applied Behavioral Science, 38(2): 216-244.

2. $\quad$ Bergsten, C. F. 2002. A renaissance for U.S. trade policy? Foreign Affairs, 81(6): 86-98.

3. Bhagwati, J. 1999. Free trade: Why AFL-CIO, The Sierra Club and Congressman Gephardt should like it. American Economist, 43(2): 3-12.

4. Cakici, N., Hessel, C., \& Tandon, K. 1996. Foreign acquisitions in the United States: Effect on shareholder wealth of foreign acquiring firms. Journal of Banking \& Finance, 20(2): 307-329.

5. Conn, R. L. \& Connell, F. 1990. International mergers: Returns to U.S. and British firms. Journal of Business Finance \& Accounting, 17(5): 689-712.

6. Datta, D. K. \& Puia, G. 1995. Cross-border acquisitions: An examination of the influence of relatedness and cultural fit on shareholder value creation in U.S. acquiring firms. Management International Review, 35(4): 337359.

7. Davis, R. \& Nair, A. 2003. A note on top management turnover in international acquisitions. Management International Review, 43(2): 171.

8. FactSet Mergerstat. 2004. FactSet Mergerstat's M\&A Roundup in 2004. K. Kunert www.mergerstat.com.

9. FactSet Mergerstat. 2006. FactSet Mergerstat Release: Global M\&A Wrap Up for 1Q06. K Kunert.

10. Global Finance. 2006. Telecom, energy deals keep M\&A boom going. In G. Platt (Ed.), Global Finance, Vol. 20: 71. New York.

11. Harford, J. 2005. What drives merger waves? Journal of Financial Economics, 77(3): 529-560.

12. Harris, R. S. \& Ravenscraft, D. 1991. The role of acquisitions in foreign direct investment: Evidence from the U.S. stock market. Journal of Finance, 46(3): 825-844.

13. Le Figaro. 2006. Vivendi shares boosted by takeover speculation (Spéculation autour de Vivendi).

14. Levitt, T. 1983. The globalization of markets. Harvard Business Review, 61(3): 92-102.

15. Lincoln, E. J. 2001. Arthritic Japan: The Slow Pace of Economic Reform. Washington, D.C.: Brookings Institution Press, pp. 212-213.

16. Mann, C. L. 1999. Is the U.S. Trade Deficit Sustainable? Washington, D.C.: Institute for International Economics, pp. 29-44.

17. Markides, C. \& Oyon, D. 1998. International acquisitions: Do they create value for shareholders? European Management Journal, 16(2): 124-135.

18. Mody, A. 2004. Is FDI integrating the world economy? World Economy, 27(8): 1195-1222.

19. Moeller, S. B. \& Schlingemann, F. P. 2005. Global diversification and bidder gains: A comparison between cross-border and domestic acquisitions. Journal of Banking \& Finance, 29(3): 533-564.

20. Park, K. M. \& Dittrich, K. 2004. International, technology-driven strategic alliances: Competition and cooperation in the global media and entertainment industry. In N. Delener \& C. Chao (Eds.), Global Business and Technology Association: Navigating Crisis and Opportunities in Global Markets: 588-595.

21. Reich, R. B. \& Mankin, E. D. 1986. Joint ventures with Japan give away our future. Harvard Business Review, 64(2): 78-86.

22. Selden, L. \& Colvin, G. 2003. M\&A needn't be a loser's game. Harvard Business Review, 81(6): 70-77.

23. Shleifer, A. \& Vishny, R. W. 2003. Stock market driven acquisitions. Journal of Financial Economics, 70: 295311.

24. Shoppa, L. 1997. What American Pressure Can and Cannot Do. New York: Columbia University Press.

25. Vambery, R. G. \& Gabberty, J. W. 1999. National policy impacts on strategic global marketing for U.S.firms, Contemporary Developments in Marketing: 227-246. Paris: Editions ESKA.

26. Vambery, Robert. G. and James. W. Gabberty, (2006). Endless Surpluses: Japan's Successful International Trade Policy. Journal of the American Academy of Business, 10 (1), 264 - 272.

27. Vambery, Robert G. and Peter Mayer, (2008). Aligning Global Business Strategy Planning Models with Accelerating Change. Journal of Global Business and Technology, Volume 4, Number 1, Spring 2008, 44-64 